\title{
EMOTIONS AND EMOTIONAL INTELLIGENCE BEYOND WORDS IN THE POETRY OF ROSE AUSLÄNDER, SELMA-MEERBAUM EISINGER, PAUL CELAN, AND DAN PAGIS
}

\author{
Raluca Ștefania PELIN ${ }^{*}$ \\ Alexandru Ioan Cuza University of Iași, Romania
}

\begin{abstract}
Emotions are sometimes concealed in barely observable gestures or facial expressions.. Poetry follows a similar path when it hides an abundant load of emotional states behind the scarcity of words which are therefore endowed with a manifold power of expression. The secret to resonating with the message of the poet lies in the readers' ability to approach poems from the perspective of emotional intelligence in order to become aware of the poet's emotional states beyond words - states that stirred such a flux of thoughts and words, to find the bridge that links them to the poet in a particular common understanding of life issues, and to become aware of their own emotions, not only those felt while reading the poem, but their own emotional manifestations in similar contexts. The poetry of Rose Ausländer, Selma-Meerbaum Eisinger, Paul Celan, and Dan Pagis takes the readers to realms where suffering is intensely felt and where compassion and empathy take shape so as to change the readers' perspective upon the world. The English versions of the poems are faithful mediators of these emotional states to readers belonging to various cultural backgrounds and historical contexts, and convey the powerful message that human inner battles transcend all borders and become precious life lessons.
\end{abstract}

Keywords: emotions, emotional intelligence, emotional competences, Holocaust writers, Chernivtsi, reading transaction

Life is such an unexpected mystery for people. It is made of events of all sorts, some of which are given a tremendous intensity by the historical and social context in which some are destined to live. The first half of the previous century represented a time of great upheavals and troubling incidents that led to an unbelievable revelations about human nature. Man rose against his own kind

*ralustefpel@gmail.com 
and a terrible void of human values such as empathy and understanding emerged. Behind all human action however, there is an overwhelming weight of emotional input. Reason alone cannot be held responsible, and if people thought they were reasonable in their actions and emotional manifestations, so were those who suffered the consequences of those actions that sprang from the load of emotions. Unimaginable as it may be, history is essentially the consequence of emotions together with thoughts translated into acts that have either lifted up or brought people down.

Emotions are more than transient states that are suddenly triggered by some intense happenings. As Seymour Epstein opines in his book Constructive Thinking, The Key to Emotional Intelligence, emotions errupt from one's way of thinking and are always filtered through our thinking.

Emotions ... are almost always produced by the interpretation of events, which means that emotions are almost always produced by thoughts. If you want to change the way you emotionally react, you have to change your thinking. This, of course, has enormous implications for improving emotional intelligence. (7)

History has proven that some people lack the skills of emotional intelligence. Their acts have affected people who either had these competences or acquired them along the way in order to survive. In C. S. Lewis's opinion,emotions "can be reasonable or unreasonable as they conform to Reason or fail to conform. The heart never takes the place of the head: but it can, and should, obey it” (19).

What happened around the time and during the Second World War was evidence of the fact that people making decisions manifested a rather unreasonable side of their emotional intelligence. No matter how praiseworthy a strategic global act may be, if it makes innocent victims and instills pain in many generations to come, it has failed to reach its goal, even when there is an illusory benefit for the winners.

A time of unspeakable anguish due tohatred reached Bukovina and Chernivtsy and the young people living there had to face the death of their peaceful and joyful existence in a land of thriving culture. Part of this anguish was a painful separation from a language that transformed overnightfrom a beloved means of expressing thoughts and feelings into a feared enemy: the German language of the perpetrators. The words of Ilana Shmueli, a Jewish writer born in Chernivtsy, are very telling: "I missed the close connection to a language, with words that lived in me and in which I lived" (cf. Hirsch, Spitzer 72).

The German language gave the writers living in Chernivtsy "access to a rich literary and cultural realm" and "provided them with hope of an ongoing continuity with that realm". However,one of the tragedies that marked the production of Bukowina's Jewish German speaking poets was that "these Jewish 
poets wrote in German, a special tragedy at a time when even Jewish writers living in Germany itself were in the process of being exiled from their mother tongue" (Hirsch, Spitzer 93).

The shock of being faced with a separation both from their dear ones and from the language they used to connect with them, speaking it in their homes, was, of course,also accompanied by the emotion of grief. It was the grief of separation from the dear ones, of falling victim to the inhuman treatment in concentration camps, the grief of witnessing the death of the loved ones, of hopelessness and helplessness. It is precisely this grief that the readers perceive in some of the poems written during those terrible times and afterwards, a grief that projects the readers into the experience of the writers and makes them aware of the historical and the social realities determining those works of art. It is the grief the poets themselves had to face while looking back and reliving the moments of their profound distress. Grief must take a strong poetic shape so as to break all temporal and cultural boundries in order to be seen and felt in its own might. Some of the Jewish poets from Bukowina chose either to express grief in its crude and consuming pain, like Paul Celan and Selma Meerbaum Eisinger, or to clothe it into the garment of irony, like Dan Pagis. In either case, the effect on the readers should be to awaken them from any form of intellectual and emotional slumber and make them aware of the impact history had on the destiny of certain people through the choices other people made or consented to.

Pain and suffering find various channels to be relieved. For the more skilled, the channel was literature, be it prose or poetry. Although Peter Goldie asserts in his book The Mess Inside. Narrative, Emotion, and the Mind that "grief is an emotion best understood and explained through a narrative" (56), poetry is a trustworthy rival as it does not ask for many words and elaborate descriptions of events that cause a parallel grief. It purely allows for a simple, but deeply felt cry of anguish. A word can carry an immense weight of meaning, be it the whisper or sigh of an emotionally tormented or exalted soul. However, one may wonder about the depth to which poems or narratives resonate in the minds of readers. Are readers'emotions only passively involved for the short span of reading, or is there a more powerful influence that these emotions can exercise in order to prompt readers to take action beyond the literary moment? Norman Holland raises a very reasonable argument: "Involved in literature, however, we separate action from emotion. Because we know that we cannot possibly change the represented situation we are perceiving, we cognitively inhibit the action the emotion would normally prompt" (103). The readers may indeed inhibit the action the emotions stir while reading. Nevertheless, when one reads texts that are the representation of historically and socially troubling contexts, the emotion stirred while reading may linger in the reader's heart and mind and give rise to a commitment never to let similar atrocities happen again. 
Some poems are simply meant to be cries awakening a humanity who chooses to remain passive.

Given the wide array of emotional states, some of the poems written by the poets going through various extreme circumstances confront the readers with grief, shock, anger, bewilderment, despair, or hopelessness. How do the readers recognise these emotions beyond the words that weave the fabric of the poem? Words carry a profound emotional message that can only be understood by diving into the reality that brought about such manifestations of the spirit. For example, Peter Goldie views grief as a process and therefore one should "look to what sustains it through various stages" (63). He continues sayingthat "when we turn to the explanation of a process, we look beyond just what sets the process off; we look also for the factors that explain why the process took the turns it did, at those times and in those ways" (63). Even if this seems to describe a normal way of dealing with strong emotions in every day life, the reader may follow the same path so as to reach the core of emotions the poets expressby means of their poems. Grieving, for instance, is a process that can either hopelessly trap the person that has been through trying times or inspire the tried person to write and release the heavy load of troubling thoughts into words. The written words may echo in the readers' mind with a certain force based on their readiness to let words work a profound understanding of the circumstances of the suffering encountered. In Peter Goldie's view, one can be relieved of a traumatic experience by achieving a kind of closure - an emotional closure:

being able to look back in the right way on one's past life from one's present external perspective, not just seeing the causal connections, and making sense of why one then thought, felt, and acted as one then did, but also making an external evaluation and having emotional responses that one feels are the appropriate ones to what happened. (71)

The medium of poetry could be just the means through which the poet can accomplish this emotional closure by giving unutterable thoughts and sighs the shape of words that best carry their emotional load. Lines are like the bits of language that people use when they are overwhelmed with feelings. They allow for pauses, interrupted or concise ideas, and lack of punctuation. They allow the echo of the wordsto continueand awaken all readers to a deep awareness of what has been and should not be again: "Telling really is important here, as psychoanalysis - the talking cure - reveals: it is sometimes only in the telling that one can come to see the past from the proper perspective - to work things through in one's mind" (Goldie 72).

Since literature can spring from the experience of writers, the way realities are given shape in words sheds light on the emotional life of writers and on the emotional potential of readers. Writers' and readers' self-awareness and 
awareness of others beyond the written words are better understood if analysed through the filter of emotional intelligence. A pragmatic definition of the concept may sound too dry for the world of literature. Nevertheless, its truthfulness transcends all borders since it reveals facts about the human soul, mind, and perception:

Emotional intelligence involves the ability to monitor one's own and others' feelings and emotions, to regulate them, and to use emotion-based information to guide thinking and action. The competencies involved in emotional intelligence include (a) appraising and expressing emotions in the self and others, (b) assimilating emotions and thought, (c) understanding and analyzing emotions, and (d) regulating emotions to promote emotional and intellectual growth. ... These competencies facilitate successful coping through a number of distinct processes - they forestall rumination, prompt emotional insight and disclosure, and often lead to increased use of social support. (Salovey et al 141)

In the world of literature, the readers witness the above concepts in the way writers choose to express their strong emotions and the way they cope with them, leaving them the hard mission of recognising the emotional message beyond the written words, of analysing and understanding them in order to make sense of the entire context that gave shape to such works of art. The end of this process of diving into the thoughts and the emotional life of the poems should later translate into empathy and a commitment to become aware of the choices and circumstances that cause suffering.

In his book Working with Emotional Intelligence, Daniel Goleman proposes an "Emotional Competence Framework" that comprises the above mentioned competences into two areas that highlight the personal and the social competences of an emotionally intelligent person. Of particular interest when approaching literary works are two skills in the area of Personal Competence:

\section{Self - Awareness}

Knowing one's internal states, preferences, resources, and intuitions

- Emotional awareness: Recognizing one's emotions and their effects

- Accurate self-assessment: Knowing one's strengths and limits

- Self-confidence: A strong sense of one's self-worth and capabilities

\section{Self-Regulation}

Managing one's internal states, impulses, and resources

- Self-Control: Keeping disruptive emotions and impulses in check

- Trustworthiness: Maintaining standards of honesty and integrity

- Conscientiousness: Taking responsibility for personal performance

- Adaptability: Flexibility in handling change

- Innovation: Being comfortable with novel ideas, approaches, and new information (32). 
The Social Competence that complements the Personal Competence and is especially meaningful in approaching literature is empathy: "Awareness of others' feelings, needs and concerns" and its core subcomponent: 'Understanding others: Sensing others' feelings and perspectives, and taking an active interest in their concerns"' (33). Among the social skills are those of "Change catalyst: Initiating or managing change" and "Building bonds: Nurturing instrumental relationships" (34) which gain significance when writers and readers try to transcend their own worlds and meet on the ground of words, feelings, and meaningful imagery.

Going through this list of competences one may find that some aspects are very relevant for readers and others for writers. From the perspective of the readers, Personal Competence would imply being aware of one's thoughts and feelings while reading a text. Consequently, readers should be able to channel their emotions and guide them towards positive outcomes. Social Competence is actually the characteristic that should be mostly activated while approaching literary texts that convey powerful messages with a strong emotional load. The most important and the most frequently analysed competence in tackling literature is empathy. Understanding the feelings and the perspective of the writer is sometimes essential in unlocking the message of a text.

Social skills are not only the readers' best asset , they are also the asset of the writers trying to reach the audience and raise their awareness so that they will make better life choices. If the text manages to find a strong echo in the mind and heart of readers, then the writer can be said to possess the gift of effectively communicating ideas and of building an unseen bond with readers. Writers may therefore act as change catalysts if their works succeed in raising readers' awareness about the historical and social facts that are vividly reflected in their works.

Richard J. Davidson, in his book The Emotional Life of Your Brain, offers what could be regarded as a sort of concise summary of the competences analysed by Daniel Goleman, and highlights some tremendously meaningful and life-saving competences. Whereas they may be regarded as essential in the life of writers, others should become part of the reader's ability to approach texts. The six emotional styles he proposes are:

Resilience: how slowly or quickly you recover from adversity.

Outlook: how long you are able to sustain positive emotion.

Social Intuition: how adept you are at picking up social signals from the people around you.

Self-Awareness: how well you perceive bodily feelings that reflect emotions.

Sensitivity to Context: how good you are at regulating your emotional responses to take into account the context you find yourself in.

Attention: how sharp and clear your focus is. (xiv) 
The key to happiness is to master all the emotional competences mentioned above. However, life forced writers to face such circumstances that some of these competences became the only chance to mental, emotional, and physical coping and survival. Both writers and readers can benefit from displaying all these competences in the act of producing and approaching literary texts.

Some of these competences may be identified as having been the gift of some writers and the key element that kept them balanced and gave them the will to survive and bring themselves back to living. For some, the skill of resilience must have been built in the act of writing, as writing can certainly represent a therapeutic process meant to save one and give inner struggles a voice. For others, the competence of outlook has been another vital fuel that kept them alive and able to cope with adverse realities. Together with self-awareness, these two skills help writers face themselves and share their inner self with the readers in an artistic act from which everyone can emerge stronger and more understanding.

The question that naturally arises now is: Why should the readers approach the literary text from the perspective of emotional intelligence? There may be various reasons enumerated here. One may be the exchange of meaning between the author and his world and the reader and his world that ensues in the process of reading. Another reason may be the impact on increasing the readers' self- awareness and the awareness of others such as the writers and their world. A third one may be the text itself. By means of the experience it presents or the emotions it evokes in connection to a particular experience, the text may be a mirror in which the readers see their own experience or are offered an alternative point of view. Writers who lived, overcame, and wrote in or after extremely dire circumstances offer valuable lessons in the importance of emotional intelligence competences.

Another question may refer to the factors that facilitate the reception of texts from the perspective of emotional intelligence. Reception is certainly facilitated not only by the linguistic versatility of the readers, but also by their readiness and willingness to understand the life context and the human being behind the lines. The bridge that facilitates communication between the readers and the text when readers lack knowledge of the writer's language is skillfully built by the translator who has to possess emotional intelligence skills in order to put himself in the frame of mind of the writer and be as loyal as possible to the original message. A faithful rendering of the emotional content of the poems is the result of the emotional intelligence competences the translator possesses which enable him to facilitate the understanding of the message delivered by the writer: "Being able to appraise and communicate one's own and other people's emotions is a key aspect of the intercultural communication, and therefore a key skill for translators and interpreters” (Hubscher-Davidson 333). Translators 
achieve their best work when they manage to render metaphors, metonymy, and irony with such skill that the emotional impact produced on the reader is the same as the one caused by the original: "The implication for T\&I is that the translation of texts with high emotive potential is likely to be more successfully undertaken by an emotionally intelligent translator” (Hubscher-Davidson 334).

A wide gallery of poets from Bukowina opens before our eyes and their writings are meant to enlighten us as to what disturbed the inner balance of their soul. In her poem Czernowitz before the Second World War, Rose Ausländer paints a very truthful image of what the place looked like before the Second Wold War: the peaceful and happy life of the people of various ethnicities and speaking four languages. Harmony was common in diversity until "bombs fell". The poem takes readers from one emotional state, that of tranquility, happiness, and joyful communication, to that of shock when bombs fell. The writer herself is blatantly and painfully self-aware of what was and what was about to come. The translation done by Vincent Homolka is very faithful to the original and keeps the simplicity and the intensity of authorial thoughts.

\section{Czernowitz before the Second World War}

Peaceful hill town encircled by beech woods

Willows along the Pruth

rafts and swimmers

Maytime profusion of lilac

About the lanterns

May bugs dance

their death

Four languages

Speak to each other

enrich the air

The town

breathed happily

till bombs fell

\section{Czernowitz vor dem Zweiten Weltkrieg}

Friedliche Hügelstadt

von Buchenwälder numschlossen

Weiden entlang dem Pruth

Flösse und Schwimmer

Maifliederfülle

um die Lanterner

tanzen Maikäfer

ihren Tod

Vier Sprachen

verständigen sich

verwöhnen die Luft

Bis Bomben fielen

atmete glücklich

die Stadt

In her poem Amazement II, the readers experience a close encounter with a very self-aware writer who acknowledges her deeply contrasting emotional experience. The message relies on a play upon words that are meant to strike a very sensitive cord in readers themselves. It is history in a nutshell filtered through the soul of a torn writer who hardly seems to be able to nurture a positive outlook and makes a superhuman effort to nourish an expectant hope. 
The translators, Anna Maria Begemann and Elana Levy, have certainly captured the meaning of every word that reveals the feelings struggling inside the poet:

\author{
Amazement II: \\ Behind my cheerfulness \\ breathes the grief \\ Behind the grief \\ stands my amazement \\ beyond cheerfulness and grief \\ and beyond all \\ what was \\ what is and \\ what will be
}

\author{
Staunen II \\ Hinter meinem Frohsinn \\ atmet die Trauer \\ Hinter der Trauer \\ Steht mein Staunen \\ über Frohsinn und Trauer \\ und überalles \\ was war \\ was ist und \\ was sein wird
}

It looks as if each temporal stretch has its own feeling attached to it: cheerfulness is "what was", grief is "what is" and amazement is connected with "what will be".

From a poem that mirrors such powerful self-awareness, in which the writer balances inner states with an incomparable force of self-control and trustworthiness, there comes a poem that shifts the perspective to the other emotional intelligence competence - that of social competence, which relates to being aware of the other, the dearest and closest one, to empathising with this one's being and thinking. The translator, Vincent Homolka, manages again to keep the profound message from the original language and render it with absolute faithfulness. Here, Rose Ausländer paints a magnificent portrait of her mother with the grace of a person that has been so close to her, a closeness that gives her insight into her innermost desires. The wish of being a nightingale recalls the impressive gift nightingales have of producing a multitude of sounds. This giftedness is majestically illustrated by the fact that the nightingale in this poem has the ability to sing about everything that is meaningful to somebody's life - from the mere soothing lullaby that lulls a child to peaceful rest to the peaceful and beautiful land where people could enjoy a serene existence. Nevertheless, the song has the unexpected and rather opposite effect of throwing the listener into a "sleepless dream." Here is the moment where the readers have to display their skills in reading the mind and feelings of the writer beyond the words used. They have to infer precisely that state in which the mind and heart are hopeless in the expectation of a restoration of the beauty of life close to the dear and loved ones. 


\section{My Nightingale}

My mother was once a doe

The golden brown eyes

the grace

remained from her time as a doe

Here she was

half angel half human -

the middle a mother

When I asked her what she would

have liked to be

she said: a nightingale

Now she is a nightingale

Night after night I hear her

in the garden of my sleepless dream

She sings the ancestors' Zion

she sings old Austria

she sings the mountains and beech

woods

of the Bukovina

Night after night

my nightingale sings me

lullabies

in the garden of my sleepless dream

\section{Meine Nachtigall}

Meine Mutter war einmalein Reh

Die goldbraunenAugen

die Anmut

blieben ihr aus der Rehzeit

Hier war sie

halb Engel halb Mensch -

die Mitte war Mutter

Als ich sie fragte was sie gerne geworden wäre

sagte sie: eine Nactigall

Jetzt ist sie eine Nachtigall

Nacht um Nacht höre ich sie

im Garten meines schlaflosenTraumes

Sie singt das Zion der Ahnen

sie singt das alte Österreich

sie singt die Berge und Buchenwälder

der Bukowina

Wiegenlieder

singt mir Nacht um Nacht

meine Nachtigall

im Garten meines schlaflosenTraumes

Beyond the words of these poems there is the great emotional force of a writer who survived the ghetto and overcame the horrors of the Second World War . Social intuition and sensitivity to the context, resilience and a commitment to keep a positive outlook seem to have been the gifts of survivors. Attention is the gift of readers who dive into a world of past suffering and the key that unlocks understanding. The more readers are aware of the life circumstances that led to the creation of such verses, the more powerful and clearer the message of these verses. It is the profound awareness of the impact of history that sheds light on the written, silent words.

A more moving example comes from a young person whose life was doomed to end in a concentration camp. Selma-Meerbaum Eisinger's young dreams and emotions found expression in the poems she wrote. Entering the universe of her thoughts and feelings, readers are called to summon all the emotional intelligence skills they possess in order to grasp the profound meaning beyond the words left on paper. A deep awareness of what this poet felt means a deep awareness of our own feelings, which we, as readers, have never dared to speak. 


\section{Dreams}

My nights are

interwoven with dreams

That are as sweet as new wine.

I dream that blossom falls from the trees

That, to cover and wrap me incline.

And all these blossoms

Change into kisses

As warm as red wine

But as sad as the butterflies that

know

They must be extinguished by the

light in decline.

My nights are

interwoven with dreams

That are as drowsy and heavy as sand.

I dream that, from dying trees,

Leaves fall into my hand.

And all these leaves

Become hands

That sooth like the tumbling of sand

But as tired as butterflies that know they will end

Before their sunbeam is found.

My nights are interwoven with dreams

That the pangs of yearning show.

I dream that, falling from trees, Are flakes of tinkling snow.

And all these flakes

Become my tears.

Hot and confused did they fall-

Seize my dreams, O my beloved, For, you, eternally longing, they call.

\section{Träume}

Es sind meine Nächte

durchflochten von Träumen, die süß sind wie junger Wein. Ich träume, es fallen die Blüten von Bäumen

und hüllen und decken mich ein.

Und alle diese Blüten, sie werden zu Küssen, die heiß sind wie roter Wein und traurig wie Falter, die wissen: sie müssen

verlöschen im sterbenden Schein.

Es sind meine Nächte durchflochten von Träumen, die schwer sind wie müder Sand. Ich träume, es fallen von sterbenden Bäumen die Blätter in meine Hand.

Und alle diese Blätter, sie werden zu Händen, die zärteln wie rollender Sand und müd sind wie Falter, die wissen: sie enden noch eh' sie ein Sonnenstrahl fand.

Es sind meine Nächte durchflochten von Träumen, die blau sind wie Sehnsuchtsweh. Ich träume, es fallen von allen Bäumen

Flocken von klingendem Schnee.

Und all diese Flocken sie werden zu Tränen.

Ich weinte sie heiß und wirr begreif meine Träume, Geliebter, sie sehnen

sich alle nur ewig nach dir. 
The translator David Paley attempts a faithful rendering of the original message by keeping the imagery and the verbs of movement as vivid as possible. An emotionally intelligent reader of the poem would probably notice the way the German language highlights certain parts of the verses "Es sind..." as an anticipation and a preparatory phrase for what is to come. It is the nights that are interlaced with dreams. The darkness of the nights is pierced by the power of dreams. Dreams are hope and the imagery created around them pertains to the hope of the one that loves and dreams about a fulfilment of the feeling. The last stanza in English loses a bit of the profound meaning it has in the German language. The original unveils a writer who cries tears, ardently and confused, whereas in the English version the tears simply fall hot and confused. The change of focus certainly diminishes the strength of empathy that the readers may feel while witnessing a person - beyond the written lines - who suffers and gives voice to such longing and pain. The German verb begreifen in this stanza can also be understood to mean more than "seize" as the English version suggests. In the light of the need to perceive and understand others as the key to communication, the writer wants the beloved to "understand" or "become aware" of her dreams that long for him.

Paul Celan, a writer who has survived the horrors of the Holocaust, but who lost dear ones to it, offers another perspective of a poet on the dearest and closest one - the Mother. Michael Hamburger who translated the text kept the message of the poem as clear and as loyal to the original as possible. The poet builds an almost natural bridge between nature and the beloved Mother. The words are infused with sadness. The poet was so attached to his homeland, Ukraine, and to a Motherhe lost far too quickly and cruelly, that each image of nature is followed by thoughts about the dear Mother. It is as if nature is more fortunate to have survived the cruelty of people - "my mother's hair was never white". Her right to grow old was brutally denied. The soul of the writer cries out in despair that his "quiet", "gentle mother" can no longer return. Her good heart was stopped by lead and her eternal tears will mourn "for everyone".

\section{Aspen Tree}

Aspen Tree, your leaves glance white into the dark.

My mother's hair was never white.

Dandelion, so green is the Ukraine.

My yellow-haired mother did not come home.

\section{Espenbaum}

Espenbaum, dein Laub blickt weiß ins Dunkel.

Meiner Mutter Haar ward nimmer weiß.

Löwenzahn, so grün ist die Ukraine.

Meine blonde Mutter kam nicht heim.

Regenwolke, säumst du an den Brunnen? 
Rain cloud, above the well do you hover?

My quiet mother weeps for everyone.

Round star, you wind the golden loop.

My mother's heart was ripped by lead.

Oaken door, who lifted you off your hinges?

My gentle mother cannot

return. (24)
Meine leise Mutter weint für alle.

Runder Stern, du schlingst die goldne Schleife.

Meiner Mutter Herz ward wund von

Blei.

Eichne Tür, wer hob dich aus den

Angeln?

Meine sanfte Mutter kann nicht

kommen.

The poet's message should not stir only transitory, light emotions in readers. It should bring them to the awareness of how fortunate they are to rejoice in the presence of their own mothers and how full of hope is their prospect of being intheir homeland close to dear ones. There is such beauty and immensity in nature and such vileness in human acts of injustice that inflict pain on innocent beings. The use of the negative modal verb creates such a tumultuous feeling of hopelessness that no reader can be left impassive.

The break with the past and dear ones has been painfully experienced by the writers during the Holocaust and after. An even more tormenting problem was when language, the writers' mother tongue, no longer had the strength to contain their being and thoughts, and some decided to migrate towards a more welcoming one, in which they felt safe and found the power to express their innermost struggles. Dan Pagis was a writer who immersed himself into a new but true to his roots - language: Hebrew . He wrote in a language that freed him from the shackles of the past and allowed for strong feelings, such as justified anger, revolt, and disappointment, to be given a voice, sometimes in ironical constructions, other times in constructions revealing profound sadness and despair interwoven with faint hope.

\section{Testimony}

No no: they definitely were human beings: uniforms, boots.

How to explain? They were created in the image.

I was a shade.

A different creator made me. 
And he in his mercy left nothing of me that would die.

And I fled to him, rose weightless, blue, forgiving - I would even say: apologizing -

smoke to omnipotent smoke

without image or likeness.

The awareness of others, the perpetrators, finds natural expression in irony: "they definitely were human beings". He adopts a kind of questioning that points to a deep awareness of the things that should be uniting humans - their being created by the same Creator "in the image". Nevertheless, he seems to intentionally avoid saying whose image, since the persecutors sharedno similarities with the victims. History brought such different humans onto the stage that the writer is sure that a "different creator made" him. The historically aware and emotionally awake reader will see in these harsh words the painful tragedy of what happened during the Holocaust - innocent beings turned into smoke by those who entertained the false pretense that they were the makers of history. The image and likeness vanished because some thought that certain people should be erased from the face of the earth. Two verbs hold the focus of the tortured being - he returns to the creator "forgiving" and even "apologizing"; the first seems to turn the victim into a saint, the other into a martyr. What is naturally expected of readers of this poem is that they will not only entertain thoughts tinted with a bit of emotion such as compassion, but move even further, towards empathy and a deep understanding of the groundwork of human nature and human relations unveiled in the poem.

Even more striking is this writer'svision of a way of undoing things, of giving history the chance to make amends. The impossibility of such an act is extremely well-felt in the tone of the poet who seems to be shouting his anger and his hopelessness. The things that should be restored are depicted with such a clear awareness of one's own feelings towards what happened and an unmistakable awareness of the loss and suffering of the others. The problem in the process of undoing is thatterror will come back as part of the process. Life will be returned to its ownerspainfully, and the star will return to the place where it belongs and to the mission it has to fulfill:

\section{Draft of a Reparations Agreement}

All right, gentlemen who cry blue murder as always,

Nagging miracle makers,

quiet!

Everything will be returned to its place,

paragraph after paragraph.

The scream back into the throat.

The gold teeth back to the gums. 
The terror.

The smoke back to the tin chimney and further on and inside back to the hollow of the bones, and already you will be covered with skin and sinews and you will live, look, you will have your lives back, sit in the living room, read the evening paper.

Here you are. Nothing is too late.

As to the yellow star: immediately

it will be torn from your chest

and will emigrate

to the sky.

Reading these works of art one cannot remain passive. According to Louise M. Rosenblatt, reading involves a kind of transaction between the writer and the reader: "Reading is a transaction, a two-way process, involving a reader and a text at a particular time under particular circumstances" ("The Literary Transaction” 268). In this process, the writers use their works of art, born out of their experiences and their emotional reactions to them, to stir the memory and the consciousness of readers by sending them to realms readersmay have visited before or to new, unfamiliar ones that may create new experiences with new emotions attached to them.

the reader is active. He is not a blank tape registering a ready-made message. He is actively involved in building up a poem for himself out of the lines. He selects from the various referents that occur to him in response to the verbal symbols. He finds some context within which these referents can be related. He reinterprets earlier parts of the poem in the light of later parts. Actually, he has not fully read the first line until he has read the last, and interrelated them. There seems to be a kind of shuttling back and forth as one synthesis - one context, one persona, etc, - after another suggests itself to him.

Moreover, we see that even in these rudimentary responses the reader is paying attention to the images, feelings, attitudes, associations that the words evoke in him. (Rosenblatt, "Towards a Transactional Theory of Reading” 34)

The variety of elements involved in readers' responses to a poem highlights the relevance of feelings as a link in the decoding of meaning and the creation ofmeaning for oneself. Feelings may steer the interpretation of a text in the direction in which readers' experience or their imagination and projection potentialities take them. The transaction ends profitably for each party when the intended message of the author is taken to another level of consolidation in the consciousness of readers, offers a more complex perspective on life and the world around for readers, and endows readers with meaningful and lifelong emotional competences. Susan L. Feagin's words complete the mission of 
literary works of art with an encouraging statement for the future: "Rather than reflect our ordinary responses to real life, art should be a guard against intellectual and emotional myopia - not that it exhibits special insights or hidden truths, but that it keeps us mentally flexible. Each artwork, ideally, should contribute something to our affective and cognitive repertoire” (Hjort, Laver 60). History will follow a different course if readers choose to have new approaches to its evidence. Historical evidence is also to be found in the literary works of people who have gone through extremely disturbing times and who had the courage to write about those times and the inner battles and emotions they experienced. Readers cannot approach these writings only cognitively. In order to fully comprehend the times, the thoughts, and the soul of the people writing, it is necessary to adopt an emotionally intelligent perspective, one that stimulates readers to be aware of themselves and of others in the process of reading and to grasp the perspective of the writers themselves. A meaningful dialogue can then ensue between readers and writers, one that should motivate readers to embrace a new and meaningful attitude towards life and its challenges.

\section{Works Cited}

Ausländer, Rose. “Amazement II”. Wild River Review. The Poetry of Holocaust Survivor: Rose Ausländer. Anna Maria Begemann. https://www.wildriverreview.com/lit/poetry/the-poetry-of-holocaust-survivorrose-auslander/.Web. 9 February 2018.

---. “Czernowitz before the Second World War”. Poetry in Translation. Eastaugh, Ben, and Chris Sternal-Johnson. 2011. https://poetryintranslation.wordpress.com/2011/09/16/two-poems-by-roseauslander-translated-by-vincent-homolka/. Web. 9 February 2018.

---. "My Nightingale”. Poetry in Translation. Eastaugh, Ben, and Chris Sternal-Johnson. 2012. https://poetryintranslation.wordpress.com/2011/09/16/two-poems-byrose-auslander-translated-by-vincent-homolka/. Web. 9 February 2018.

Celan, Paul. Selected Poems. Middlesex: Penguin Books Ltd, 1972. Print.

---. "Espenbaum". agonia deutsch. Potche, Anton. March 2008. http://www.poezie.ro/index.php/poetry/1772461/print.html. Web. 7 February 2018.

Davidson, Richard J. and Sharon Begley. The Emotional Life of Your Brain. How Its Unique Patterns Affect the Way You Think, Feel, and Live - and How You Can Change Them. London: Penguin Books Ltd, 2012. Print.

Epstein, Seymour. Constructive Thinking, The Key to Emotional Intelligence. Westport: Praeger Publishers, 1998. Print.

Goldie, Peter. The Mess Inside. Narrative, Emotion, and the Mind. Oxford: Oxford University Press, 2012. Print.

Goleman, Daniel. Emotional Intelligence. Why it can matter more than IQ. New York: Bantam Books, 1995. Print.

---. Working with Emotional Intelligence. New York: Bantam Books, 1998. Print. 
Hirsch, Marianne and Leo Spitzer. Ghosts of Home. The Afterlife of Czernowitz in Jewish Memory. Berkeley and Los Angeles, California: University of California Press Ltd, 2010. Print.

Holland, Norman N. Literature and the Brain. Gainesville, Florida: The PsyArt Foundation, 2009. Print.

Hubscher-Davidson, Séverine. "Emotional Intelligence and Translation Studies: A New Bridge”. Meta: Translators’ Journal, vol. 58, no. 2, 2013, pp. 324-346. Print.

Lewis, Clive Staples. The Abolition of Man or Reflections on education with special reference to the teaching of English in the upper forms of schools. New York: HarperCollins Publishers, 2001. Print.

Meerbaum-Eisinger, Selma. "Dreams”. Poems Without Frontiers. Poems in Translation. http://www.poemswithoutfrontiers.org/Traume.html. Web. 9 October 2017.

Pagis, Dan. "Testimony” and "Draft of a Reparations Agreement”. Yad Vashem. The World Holocaust Remembrance Center. https://yadvashem.org/yv/en/education/lesson_plans/dan_pagis.asp. Web. 16 August 2017.

Rosenblatt, Louise M. “Towards a Transactional Theory of Reading.” Journal of Literacy Research, vol. 31, no. 1, 1969, pp. 31 - 49. Print.

---. "The Literary Transaction: Evocation and Response.” Theory into Practice, vol. 21, no. 4, 1982, pp. 268 - 277. Print.

Salovey, P., Bedell, B. T., Detweiler J. B., and Mayer, J. D. “Coping Intelligently. Emotional Intelligence and the Coping Process.” Coping. The Psychology of What Works, edited by Snyder, C. R., Oxford: Oxford University Press, 1999, pp. 141 - 164. Print. 